BEFORE I NOW

Vol. 1 No. 1

\title{
How to make an entrance: Piranesi comes to Ballarat
}

\section{Edward Coleridge}

FORUM ARTICLE

The inside front cover of this publication carries an image of CRCAH's front door, the main gateway to the former Ballarat Gaol. It is a magnificent example of nineteenth century masonry work. The massive bluestone blocks were carved and chiselled into a grand classical edifice, making a fitting southern finale in scale and significance to the great range of buildings on either side of Lydiard Street.

The remarkable architectural statement of a confident gold rich city runs from the ostentatious neo-classical railway station at the northern end past the Art Gallery, the Mining Exchange, the palatial former Post Office (now housing the studios of the university Arts Academy) and on along the facades of banks, hotels, theatres and churches, in a melody of styles from palladian to gothic (with some 20th century intrusions) down to the suitably 'redbrick' buildings of the Ballarat School of Mines.' Here the road swings round to the west so the range of prison buildings bookend the whole composition with a dramatic solemn coda.

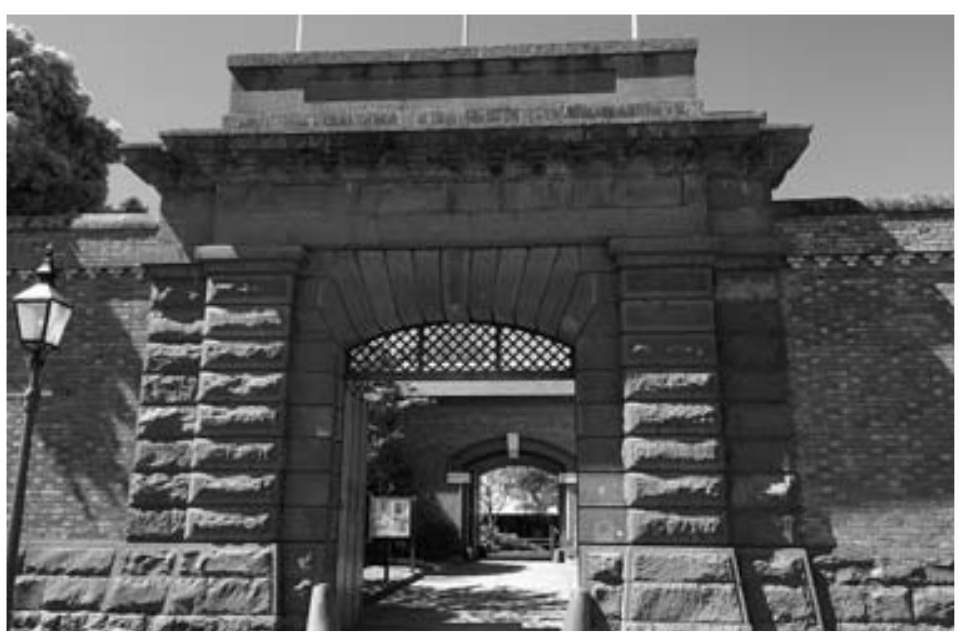

S.Wright and C.G.Ross, Ballarat Gaol, Main Gate, c1861. Photograph: Edward Coleridge, 2019.
Much of the main prison has gone except for the two well-proportioned administration buildings framing the arched entrance gateway and, on the western side, a second, and plainer, bluestone arch which pierces the castle-like turreted walls of the exercise yard. The former Courthouse rounds off the impressive frontage. That the southern end of Lydiard Street is now closed to through traffic, as part of the Federation University School of Mines precinct, enables the pedestrian visitor to safely enjoy the landscaped approach to the gateway and enter the shady courtyard where blue hydrangeas thrive during the heat of midsummer. To the right stands the mellowed brick wall of the former Prison Governor's house, the current home of the fledgling historians of $\mathrm{CRCAH}$. The arch beyond leads to the Library and other departments surrounding a well-planted piazza. It is a pleasant place to be, belying the grim purpose of the original establishment on this site: confinement, punishment and, on thirteen dawns, execution. ${ }^{2}$

Why was such trouble, skill, and visual consideration employed in housing criminals and miscreants? In this 'enlightened' age the prisons that successive governments are politically proud to build would appear, from those on the outskirts of Melbourne and Geelong, to have no architectural, aesthetic or moral quality at all.

(c) The Author(s) [2019].

Published by the Collaborative Research Centre in Australian History, Federation University Australia. All rights reserved.
Was this awesome cyclopean gateway created to say to the arriving guests of Her Majesty, either Abandon hope as ye enter here or This is the grandest front door you will ever have? Or was it, equally, a visibly stern warning at the end of a street of luxury and 
success of the perils of delinquency and moral turpitude? And why did the designers of this building take so much trouble with the two entrances, and the masons so skillfully carve the adamantine stone into quoins, voussoirs, keystone and entablature - the architectural language of Imperial Rome?

But it is not unique. All over Victoria in the 19th century prisons were installed in or near the centre of towns and several followed the same template, the appearance varying according to the terrain and the materials available. Far away in Beechworth there is a mirror image of Ballarat's facade built in a warm golden granite, quarried locally. In Ararat the prison stood on a hill above an ornamental lake with the same rhythmic arrangement of house and wall and arch looking for all the world like the grandest home of an aspiring member of the squattocracy.

In fact all the Victorian County prisons were rebuilt from earlier ad hoc versions (Ballarat's first gaol was a tree) in the mid-19th Century by the Public Works Department to the designs of the architectural team of Samuel Wright and C.G.Ross. ${ }^{3}$ They were all based on the 'panopticon' principle of radiating wings of cells projecting from a central hall where a small number of guards could observe the whole population. The concept was devised by the utilitarian philosopher Jeremy Bentham and first built at Pentonville in London in $1842 .{ }^{4}$

Lynn and Armstrong consider Sandhurst (later Bendigo) Gaol, on which construction started in 1858, was the prototype for the other country prisons and is now perhaps the best preserved. The staff accommodation on the street front is the same as at Ballarat but the arch supports a triangular pediment which would hinder the welcoming display of three flag standards atop Ballarat's gateway. Remarkably, the description for each prison states that all of the far-flung gaols of Ararat, Ballarat, Beechworth, Bendigo, Castlemaine, Geelong, and Maryborough officially opened in 1861. ${ }^{5}$ The authors do not draw attention to this fact but, if true, it was an extraordinarily coordinated achievement on the part of the Public Works Department. It was only 10 years since the first discovery of gold in Victoria in 1851. The fact that all these towns, apart from the port of Geelong, were goldmining centres suggests some connection. Strange that.

A curious concurrent event, of great symbolic significance depending on one's taste in music, is that, in that same year in Germany, Richard Wagner was writing the libretto to his monumental music drama, The Ring of the Nibelung. It took Wagner another 25 years to complete the ambitious project but, as the gold rushes took frenzied hold here, he was composing the music to the introductory work, The Rhinegold, which starts with a theft of gold. (This action sets in motion the whole vast tetralogy which ends four nights, and some nineteen hours, later when Valhalla, the home of the Gods, collapses and the Rhinemaidens get their gold back.)

However who was Wright and Ross's muse behind their interpretation of Bentham's utilitarian ideas? What gave them that extra flourish, that strong aesthetic style? The bold handling of masonry and the rich texture of the ensemble go way beyond filling the Department's brief for a country gaol. Between the well-proportioned and domestic looking staff quarters, the two archways, particularly here in Ballarat, strongly hint at the influence of an Italian architect, artist, archaeologist and printmaker - one Giovanni Battista Piranesi. 
BEFORE / NOW

Vol. 1 No. 1
Piranesi's etchings of studies of ancient Roman buildings, his Vedute di Roma, first published in 1751, were enormously influential on architects in the eighteenth and nineteenth centuries. He published hundreds of prints of views of Roman streets and squares, showing ruins and extant buildings such as the Colosseum and the Pantheon. The images were aimed at the market created by the English aristocrats and dilettanti on the Grand Tour, milordi inglesi, and French, German and other European academics and artists. ${ }^{6}$ Ficacci's catalogue raisonné records 453 plates. ${ }^{7}$

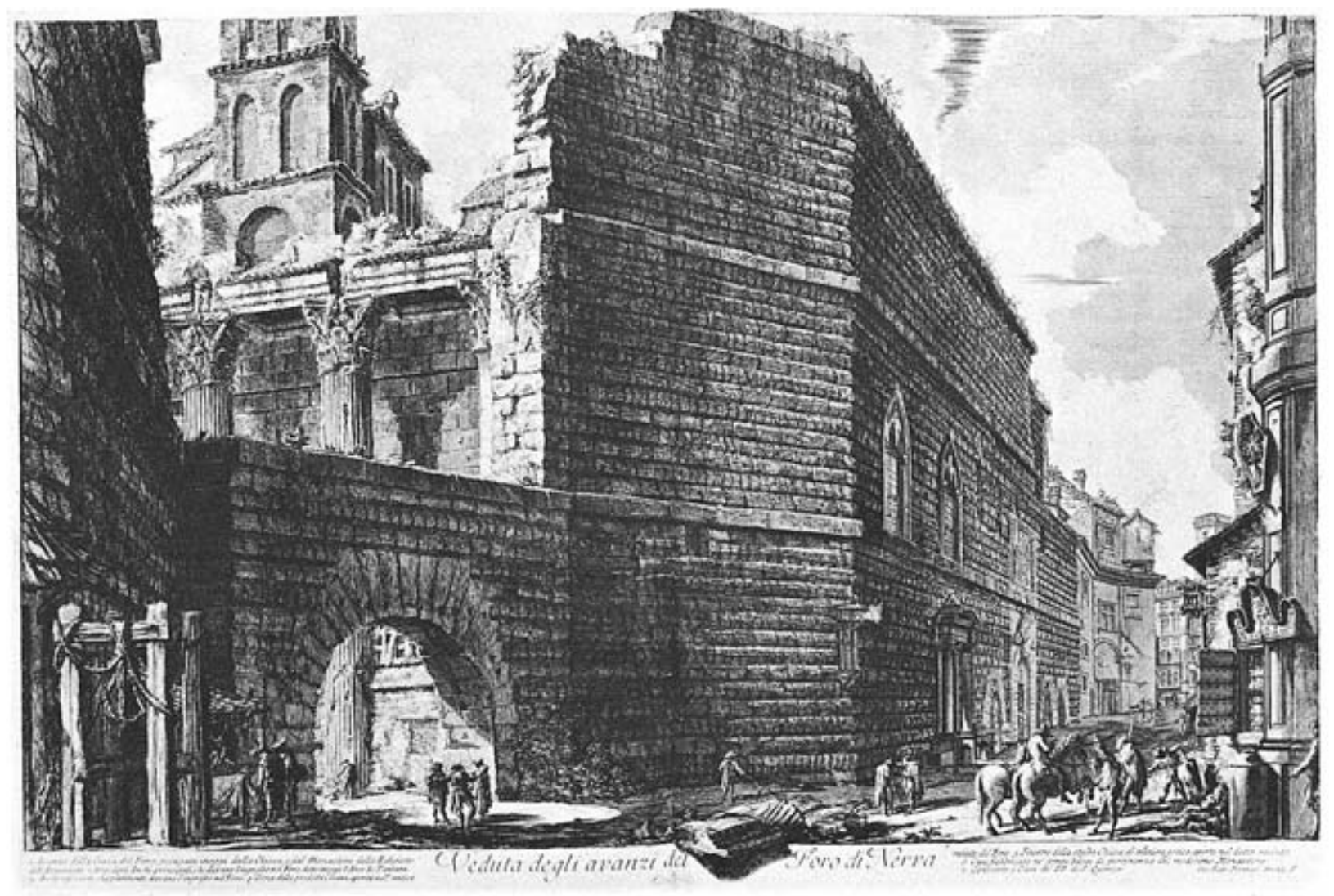

G.B. Piranesi, Veduta degli avanzi del Foro di Nerva, l'arcade et la muraille,

(Forum of Augustus [erroneously called the Forum of Nerva]), c1756, etching.

Metropolitan Museum of Art (The Met), The Elisha Whittelsey Collection, The Elisha Whittelsey Fund, 1955, 55.567.7.

Piranesi described himself as an architect although he rarely practised as such. He was too busy recording all structures the Romans built, and showing how their engineering projects were constructed, above and below ground. And he presents the jumble of remains exactly as they were, looming over, or half buried by, the modern baroque city. The images teem with life and he often exaggerates the scale of the ruins by diminishing the figures populating the scenes. He seemed to enjoy the technical challenge of combining the complexity of detail with correct perspective such as in his rendering the coffered dome of the Pantheon and the endlessly repeating tiered arches of the Colosseum. On visits to Naples he was involved in recording the excavations at Herculaneum and Pompeii.

Piranesi's images are never pedantically academic but demonstrate bold composition enhanced by dramatic chiarascuro while his Venetian heritage shows in an airy playful touch reinforced by studying in Tiepolo's studio alongside Canaletto. Paradoxically, although working almost exclusively in black ink, he evinces a Venetian sense of colour as his blacks have a richness of their own. Anderson asserts that he "learnt from 
Tiepolo how to be one of the most expressive artists ever to work in black and white". ${ }^{8}$ Whilst Holden sums up his achievement with:

His etchings turned architecture into studies of psychological intensity in which buildings become passionate dramatic actors.?

But wait there's more, as they say, and it particularly pertains to our gaol. Piranesi produced a series of images he called Carceri d'Invenzione, which are fantasies of prison interiors, though they have little resemblance to any ordinary gaol. The astonishingly complex perspectives and theatrical lighting effects in these works have influenced, and still do, generations of artists, stage designers, filmmakers and, most recently, creators of computer games. The Carceri are considered the inspiration for M.C.Escher's surrealist perspectivedefying images on show at the NGV in 2019, and strong echoes of such unsettling environments can be experienced at MONA in Tasmania. ${ }^{10}$

An illustration of the long history of the power of the Carceri on the unconscious mind (and to self-consciously name-drop) is the author of Confessions of an English-Opium Eater (1823), Thomas de Quincey, writing of his friend and fellow addict:

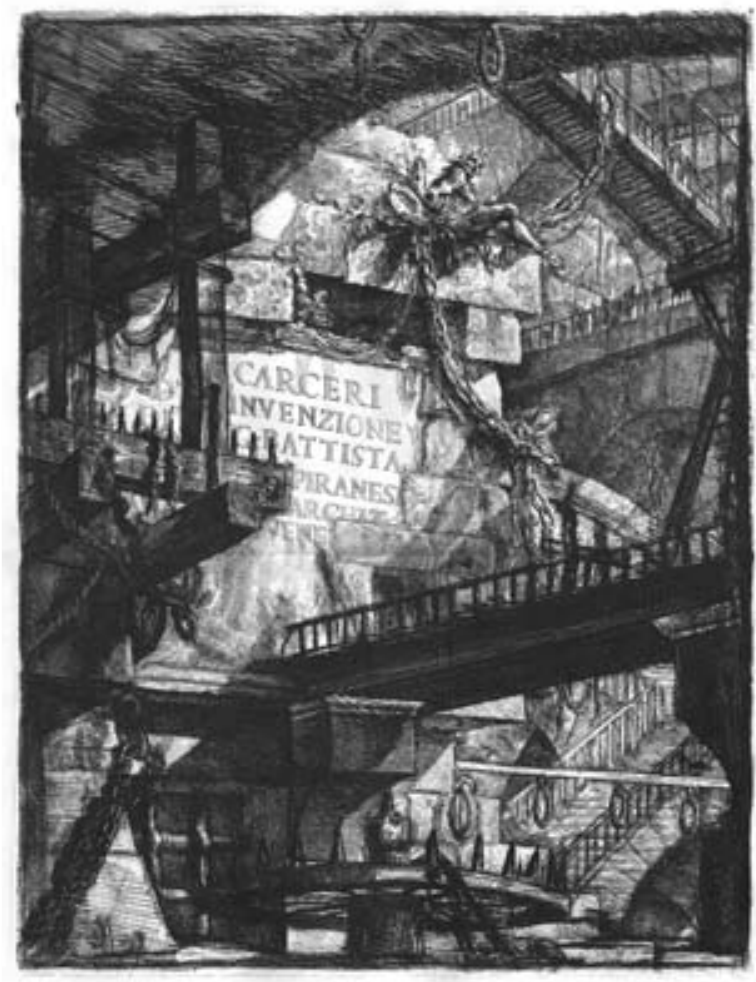

G.B. Piranesi, Carceri d'Invenzione (Imaginary Prisons) Title page 2nd State, c1761.

Print Collection, Special Collections, The University of Melbourne Library.

Many years ago, when I was looking over Piranesi's Antiquities of Rome, Mr.Coleridge, who was standing by, described to me a set of plates by that artist, called his Dreams, and which record the scenery of his own visions during the delirium of a fever."

But how does this relate to here, to a real prison in western Victoria? Could the designers of this prison have been aware of Piranesi? It might seem far-fetched but is not impossible. In the early existence of the Victorian Parliament and the State Library both institutions acquired complete sets of Piranesi's etchings of over 1,000 plates. At the same time, as Holden recounts:

Individual images mainly from the Vedute decorated the walls of the gentry and professional homes and it is hardly surprising that architects in both Australia and New Zealand possessed significant holdings [my italics].12

Whether Messrs Wright and Ross owned, or had access to, these images can only be speculated upon until further research - but it would seem quite plausible.

The most comprehensive collection of Piranesi's oeuvre was created by the great artcollecting, and architecture-commissioning, James Goold, the first Catholic Archbishop of Melbourne. This trove, now in the Baillieu Library of Melbourne University, was the basis of the Victorian State Library's magnificent exhibition, Rome: Piranesi's Vision, in 2014.

And wait, there's yet more, for James Goold and another founding father of Melbourne, one Redmond Barry, were born within a year of each other in County Cork, to very different backgrounds - and churches, and they came to Australia and thence to Melbourne for different reasons. The energetic Goold followed a conventional path up the 
BEFORE I NOW

Vol. 1 No. 1

catholic hierarchy to establish the new diocese in Port Phillip, while Carmody delicately describes the Dublin barrister's emigration thus:

After an abbreviated Grand Tour of Europe, Barry set sail for Sydney in 1839. He took a small library with him to while away the time, including works by Voltaire, Pope and Swift; no doubt in contrast to the breviary, Bible, and a few books of theology in the luggage of the missionary priest. Yet he was soon bored. Unlike Goold he was unencumbered by a vow of chastity, and had an affair with the wife of a fellow passenger. On arrival in Sydney the ensuing scandal forced him to travel further to the muddy little settlement by the Yarra, recently named Melbourne. ${ }^{13}$

The two far-sighted Corkmen were to work together setting up the foundations for the institutions that make Melbourne what it is today, chiefly the University and the Public Library (within which the National Gallery was hatched). Ironically for Goold his cathedral was not built to his 'Piranesian' classical taste. His architect, William Wardell, was a pupil of Pugin and so St Patrick's is a 'classic' example of the fashionably high gothic of the time. It still holds its own against the skyscrapers of the city.

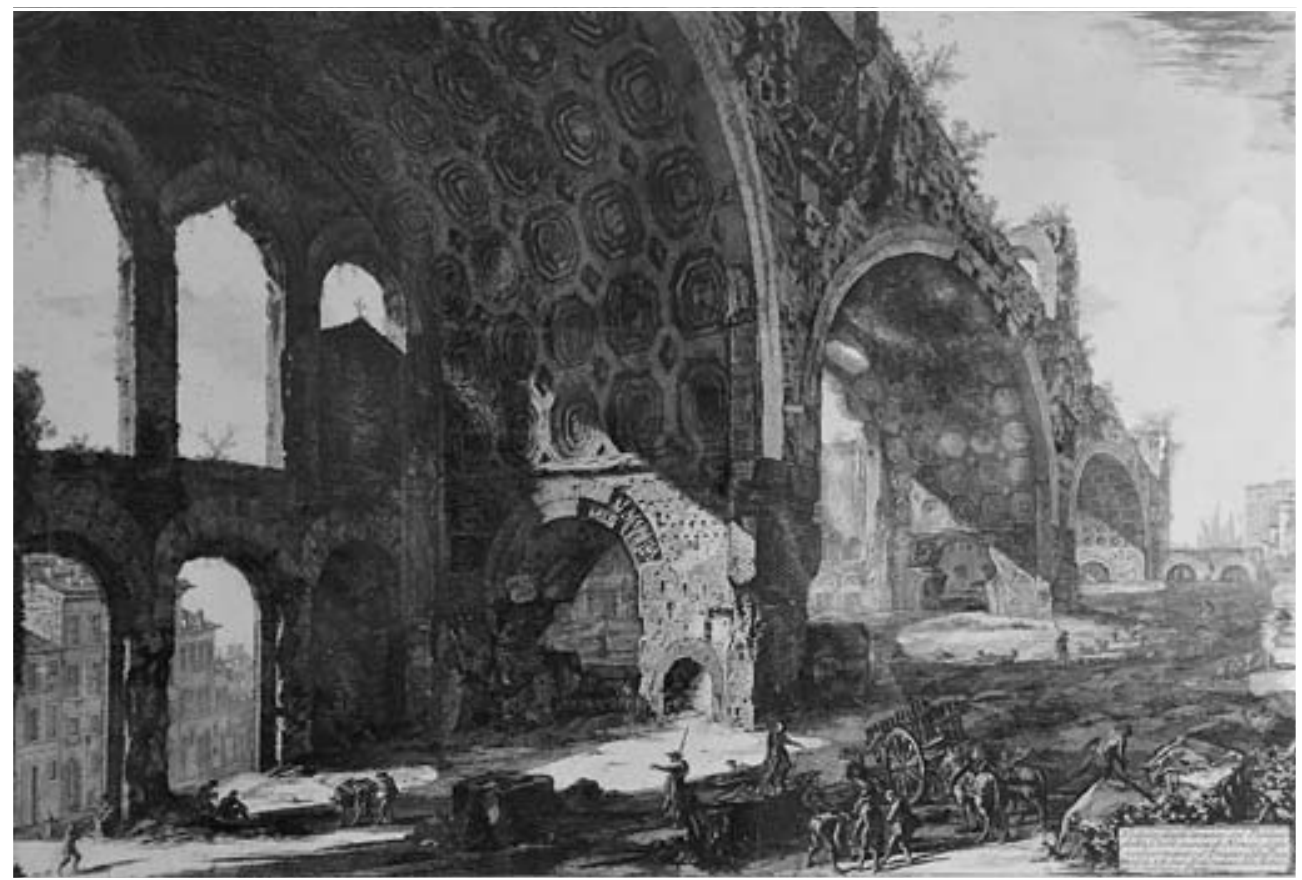

G.B. Piranesi, Basilica of Maxentius, etching and engraving, c1756. Private collection.

It is a nice, if maybe tenuous, connection that puts Piranesi, Goold and our grand gateway on the same page as the benefactor and first President of the School of Mines, the antecedent of the University of Ballarat, which became Federation University in 2014. Therefore, Judge Sir Redmond Barry was, in effect, our first Chancellor.

It is in the finely proportioned Barry Room in the original School of Mines building that the candidates of CRCAH are grilled for their PhD confirmations - and around the great horseshoe table enjoy less rigorous seminars.

Edward Coleridge | PhD candidate, CRCAH, Federation University Australia Email: e.coleridge@federation.edu.au

This research is supported by an Australian Government Research Training Program (RTP) Fee-Offset Scholarship through Federation University Australia. 


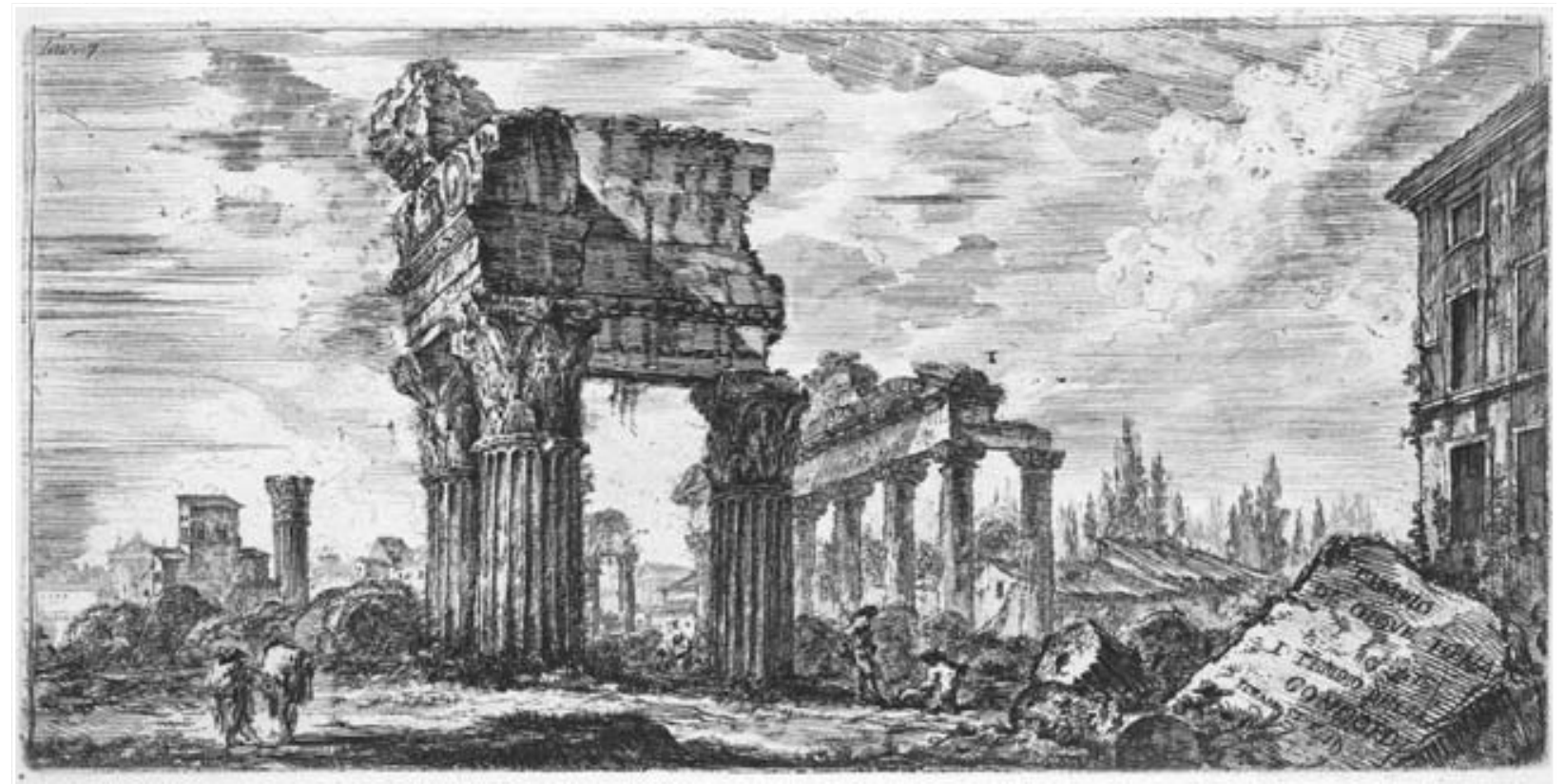

G.B. Piranesi, Plate 7: Temple of Jupiter Tonans (Jupiter the Thunderer).

1. Temple of Concord. (Tempio di Giove Tonans. 1. Tempio della Concordia.), c1748, etching.

The Met, Harris Brisbane Dick Fund, 1937, 37.45.3(74).

\section{Notes}

1 'Redbrick' is the nickname for all the English universities built in the 19th Century that being the standard material. Here the word can be free of the pejorative Oxbridge sneer.

2 See note 5.

3 From Pentonville to Pentridge, A History of Prisons in Victoria, Peter Lynn and George Armstrong, State Library of Victoria, 1996, p81.

4 Ibid p3,9. (also Heritage Victoria, Victorian Heritage Database - Former Bendigo Gaol).

5 Ibid pp 77-88. Separate entries are given for each country gaol listed alphabetically. Ballarat appears to be the only institution outside Melbourne equipped with a gallows, p79.

6 Colin Holden, Piranesi's Grandest Tour - from Europe to Australia, New South Publishing, University of NSW (with State Library of Victoria), Sydney, 2014. p78-85.

Holden vividly describes Piranesi at work in the Rome of the Grand Tourists, his sons continuing his legacy in Paris, and his impact in Australia. The illustrations in the book, timed for the exhibition Rome: Piranesi's Vision at the State Library of Victoria in 2014, which he curated, evoke the dramatic essence of 'Cavalier' Piranasi's images.

7 Luigi Ficacci, Piranesi, The Etchings, Taschen, Cologne, 2006. The SMB library holds the double volume version of Ficacci's exhaustive catalogue raisonné but the reproductions lack vitality and interpretation.
8 Jaynie Anderson, "Piranesi in Tiepolo's Venetian Studio," in The Piranesi Effect, Ch.3, eds. Kerrianne Stone and Gerrard Vaughan, New South Publishing, University of NSW, Sydney, 2015, p62.

9 Holden, p16.

10 Jane Clark writes on the unconscious influence of the Carceri on David Walsh and his architect, Nonda Katsalides, in creating the subterranean spaces of the MONA gallery in Tasmania, The Piranesi Effect, Ch 8, "Piranesi and MONA: Inspiration or Retrospective Myth" (Walsh's own words), p150-166.

11 Davis R. Marshall, "Piranesi's Creative Imagination: The Capriccio and the Carceri", The Piranesi Effect, Ch.6, p 118.

12 Holden, p157-8.

13 Shane Carmody, "The Baroque Bishop: Piranesi in the collection of J.A. Goold", The Piranesi Effect, Ch.13, p226.

The Piranesi Effect, which followed up on the State Library show of 2014, presents, with the same high graphic production values of Holden's Piranesi's Grandest Tour, accounts by a cohort of curators, historians, artists and architects on Piranesi's ongoing influences in Australia and New Zealand. 